Full length article

\title{
Recombinant nodavirus vaccine produced in bacteria and administered without purification elicits humoral immunity and protects European sea bass against infection
}

\author{
Daniel Gonzalez-Silvera ${ }^{\mathrm{a}}$, Francisco A. Guardiola ${ }^{\mathrm{a}, \mathrm{b}}$, Cristóbal Espinosa ${ }^{\mathrm{a}}$, Elena Chaves-Pozo ${ }^{\mathrm{c}}$, \\ M. Ángeles Esteban ${ }^{\mathrm{a}}$, Alberto Cuesta ${ }^{\mathrm{a}, *}$

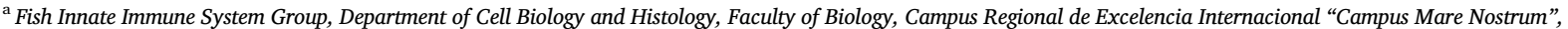 \\ University of Murcia, 30100, Murcia, Spain \\ ${ }^{\mathrm{b}}$ Centro Interdisciplinar de Investigação Marinha e Ambiental (CIIMAR), University of Porto, Terminal de Cruzeiros Do Porto de Leixões, Av. General Norton de Matos s/n, \\ 4450-208, Porto, Portugal \\ ${ }^{\mathrm{c}}$ Centro Oceanográfico de Murcia, Instituto Español de Oceanografía (IEO), Carretera de la Azohía s/n, Puerto de Mazarrón, 30860, Murcia, Spain
}

\section{A R T I C L E I N F O}

\section{Keywords:}

Nodavirus

Oral vaccines

European sea bass

Immunity

\begin{abstract}
A B S T R A C T
Viral necrosis virus (NNV) or nodavirus causes fish viral encephalopathy and retinopathy worldwide. In some cases, mortalities in aquaculture industry can reach up to $100 \%$, some species being especially sensitive as is the case of European sea bass (Dicentrarchus labrax), one of the main cultured species in the Mediterranean, with the consequent economical loses. Development of new vaccines against NNV is in the spotlight though few researches have focused in European sea bass. In this study we have generated a recombinant NNV (rNNV) vaccine produced in Escherichia coli expressing the capsid protein and administered it to European sea bass juveniles by two different routes (intraperitoneal and oral). The last being considered non-stressful and desired for fish farming of small fish, which in fact are the most affected by NNV. Oral vaccine was composed of feed pellets containing the recombinant whole bacteria, and injected vaccine was composed of recombinant bacteria previously lysed. Our results revealed production of specific anti-NNV IgM following the two vaccination procedures, levels that were further increased in orally-vaccinated group after challenge with NNV. Genes related to interferon (IFN), T-cell and immunoglobulin markers were scarcely regulated in head-kidney (HK), gut or brain. Vaccination by either route elicited a relative survival response of $100 \%$ after NNV challenge. To our knowledge, this is the first report of a recombinant vaccine followed by no purification steps which resulted in a complete protection in European sea bass when challenged with NNV.
\end{abstract}

\section{Introduction}

In the current scenario of increasing world population, together with greater awareness of the benefits of fish consumption, aquaculture activity has become essential to cover fish-products demand. Production values can be seriously compromised by the occurrence of viral diseases, which can be rapidly spread throughout fish specimens and farms. This is the case of the nodavirus (NNV), which causes Viral Encephalopathy and Retinopathy (VER) disease, which has growth in importance due to the wide range of target species (up to 120 species from marine and freshwater environments) and the massive rate mortalities it can cause (up to $100 \%$ in some species such as European sea bass Dicentrarchus labrax) [1]. NNV cause cellular vacuolation and necrosis in brain and retina, and symptoms include abnormal swimming, altered buoyancy, low feed ingestion and darker coloration among others, being especially important in larvae and juvenile fish stages [2,3]. NNV is composed by a non-enveloped capsid, formed by 180 subunits of a single protein, containing two ssRNA molecules of positive sense [4]. The RNA1 codifies a RNA-dependent RNA poly-

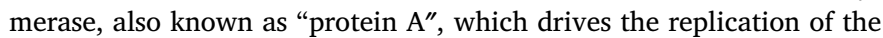
virus; and RNA2 codifies the capsid protein [1,5]. There is also a subgenomic RNA3 derived from RNA1, encoding for B1 and B2 proteins, which have a role in preventing cellular RNA silencing and premature death [6-10]. Four different genotype strains have been identified being red-spotted grouper nervous necrosis virus (RGNNV) the most common genotype found in the Mediterranean waters.

\footnotetext{
* Corresponding author. Department of Cell Biology and Histology, Faculty of Biology, Regional Campus of International Excellence "Campus Mare Nostrum", University of Murcia, 30100, Murcia, Spain.

E-mail address: alcuesta@um.es (A. Cuesta).
} 
Horizontal and vertical transmission of the NNV has been demonstrated, and the industry has applied different control strategies to avoid spreading of NNV, such as ozone sterilization, control of broodstocks and development of vaccines [1,11-13]. In practice, the application of some of these procedures can be difficult, being the prevention by means of vaccination the most promising method to control virus disease [3]. Currently, there is only one commercial vaccine against NNV (PharmaQ) and high efforts to develop novel and more effective vaccines to prevent NNV outbreaks and dissemination are being made and can be found in the literature including attenuated, inactivated, recombinant and DNA vaccines $[1,13]$.

Recombinant NNV vaccines are based in the production of the capsid protein, the only one with antigenic properties. This could be produced in either prokaryotic or eukaryotic organisms, partial or complete, and forming virus-like particles (VLPs) or not. A number of studies have shown that both innate and adaptive immune defence as well as survival against NNV challenged can be stimulated by purified recombinant vaccines. The suitability of purified recombinant NNV capsid protein vaccines has been confirmed after injection for several fish species including turbot (Scophthalmus maximus) [14], Atlantic halibut (Hippoglossus hippoglossus) [15,16], European sea bass [17,18], Asian sea bass (Lates calcarifer) [19] or several grouper species (Epinephelus spp.) [20-29]. In general, they offered medium-good protection upon infection but not all of them led to fish antibody production. Most of these vaccines were produced using the prototype Escherichia coli as the biofactory but few studies also showed good results when the vaccine was produced by the bacterium Vibrio anguillarum [24] or by the yeast Saccharomyces cerevisiae [25,26]. In addition, most of the vaccines were administered together to adjuvants and by intramuscular or intraperitoneal injection routes, which is not exempt of fish stress and suffering due to handling and injection, being particularly laborious and risky in larvae, the most susceptible stages for NNV.

Oral vaccines have arisen as a practical solution to fish vaccination in the farms. In this sense, several oral vaccines have been successfully documented against NNV. Thus, DNA vaccines were encapsulated and orally administered and partially protected Asian sea bass [30] or European sea bass [31] upon NNV challenge. For recombinant oral vaccines, they were produced in bacteria or yeast and added to the diet after protein purification, or by the encapsulation of these microorganisms into Artemia [23-27]. Based on the potential application of oral vaccines and the few studies generating and evaluating NNV vaccines in European sea bass the aim of this study was to develop a recombinant vaccine against NNV (administered by both injected and oral routes), in order to improve protection of European sea bass, a susceptible and economically important species reaching up to $100 \%$ of mortality by NNV. Our vaccine was developed using E. coli as antigen expression host, which was applied without any purification step, thus the bacteria acting as vaccine vehicle and as biological adjuvant as well.

\section{Material and methods}

\subsection{Animals}

Healthy European sea bass juveniles (Dicentrarchus labrax; 10-12 g body weight) were purchased form a regional hatchery with clear history of NNV infections and transported to the University of Murcia (Spain). Fish were kept in $75 \mathrm{~L}$ running seawater ( $28 \%$ salinity) aquaria at $24 \pm 2{ }^{\circ} \mathrm{C}$, with a $12 \mathrm{~h}$ light: $12 \mathrm{~h}$ dark photoperiod and fed daily with $3 \%$ biomass of a commercial pellet diet (Skretting). Before sampling, all specimens were anesthetized with $40 \mu \mathrm{L} / \mathrm{L}$ of clove oil, completely bled and immediately beheaded and weighed. All animal studies were carried out in accordance with the Guidelines of the European Union Council (2010/63/UE), the Bioethical Committee of the University of Murcia (Permit Number: A13150104) and the Instituto Español de Oceanografía (Permit Number: 2010/02) for the use of laboratory animals.

\subsection{Nodavirus (NNV) stocks}

Nodavirus (NNV; strain It/411/96, genotype RGNNV) was propagated in the $\mathrm{E}-11$ cell line. Cells were inoculated with NNV and incubated at $25^{\circ} \mathrm{C}$ until the cytopathic effect (CPE) was extensive. The supernatant was harvested and centrifuged to eliminate cell debris. Virus stocks were titrated in 96-well plates before use in the experiments [32].

\subsection{Production of recombinant $N N V$ ( $r N N V)$ vaccine}

We amplified the RNA2 encoding the capsid protein of RGNNV by PCR (see Supplementary Table 1 for primers) and the product ligated into the pBADM-11 vector (EMBL) using NcoI and EcoRI restriction enzymes to produce the N-terminal His-tagged NNV capsid protein (rNNV). Self-ligated or empty plasmid was used as negative control. Plasmid was then used to transform TOP10 Escherichia coli bacteria. Clones containing the plasmid were selected by ampicillin resistance and confirmed by PCR. Recombinant bacteria were grown in Luria broth (LB) and protein production induced by L-arabinose incubation for $4 \mathrm{~h}$. Proteins were electrophoresed and blotted to nitrocellulose membrane being total proteins stained by Ponceau $\mathrm{S}$ solution and the rNNV protein identified by western blotting using a commercial antiHis antibody (Invitrogen) following standard techniques.

\subsection{Fish vaccination}

For vaccine preparation, bacterial cultures were induced for rNNV overproduction, washed twice with phosphate buffer (PBS) and processed for vaccination by either oral or injection routes. For oral vaccination, whole bacteria were added to the commercial diet at $10^{10} \mathrm{cfu} /$ $\mathrm{g}$ fed and cod oil ( $100 \mathrm{ml}$ per $\mathrm{kg}$ diet) was added to seal the pellets. For intraperitoneal (ip) vaccination, bacteria at $10^{11} \mathrm{cfu} / \mathrm{mL}$ were sonicated for cell lysis on ice.

Prior to the fish vaccination the absence of NNV was confirmed by routine histology and PCR in the brain of 6 fish specimens. European sea bass fish specimens were randomly divided into 12 aquaria $(75 \mathrm{~L}$ each) with 30 fish each forming six experimental groups in duplicate. For oral vaccination, one group was fed with the commercial diet (control) or the diet containing bacteria without NNV (oral control) or bacteria producing the rNNV vaccine (oral rNNV). Fed was administrated at a rate of $3 \%$ biomass for 3 consecutive days and a boost at day 14. For ip vaccination, fish were gently sedated by $20 \mu \mathrm{L} / \mathrm{L}$ of clove oil and each fish received a single ip injection with $100 \mu \mathrm{L}$ of PBS (control), bacterial lysate without NNV (ip control) or the rNNV bacterial lysate (ip rNNV). Fish were also boosted at day 14. After vaccination, fish ( $\mathrm{n}=6 \mathrm{fish} /$ group and time) were sampled 1,15 and 30 days postvaccination (dpv). Blood was obtained from the caudal peduncles and serum samples by centrifugation at $10,000 \mathrm{~g}$ for $10 \mathrm{~min}$ at $4{ }^{\circ} \mathrm{C}$ and immediately stored at $-80^{\circ} \mathrm{C}$ until use. Head-kidney (HK), posterior gut and brain were removed by dissection, immediately frozen in TRIzol Reagent (Life Technologies) and stored at $-80{ }^{\circ} \mathrm{C}$ until use.

\subsection{NNV challenge}

Thirty days after vaccination, the remaining fish (20 per aquaria) received a single intramuscular injection of $100 \mu \mathrm{L}$ culture medium containing $10^{6} \mathrm{TCID}_{50} /$ fish of the same NNV isolate since this route of infection has been proven to be the most effective. Mortality was recorded daily as the cumulative mortality and relative percentage of survival (RPS) determined. Samples of serum and brain ( $n=6 /$ group and time) were also taken 2 days post-infection (dpi) and processed as described above. 


\subsection{Specific anti-NNV IgM levels}

Serum specific immunoglobulin M (IgM) levels against NNV were analysed following a previously used protocol [33]. Briefly, $100 \mu \mathrm{L}$ of purified NNV preparation diluted 1:5 with $50 \mathrm{mM}$ carbonate-bicarbonate buffer $\mathrm{pH} 9.6$ was used to coat flat-bottomed 96-well plates overnight at $4{ }^{\circ} \mathrm{C}$. After three rinses with PBS-T (PBS with $0.05 \%$ Tween-20), the plates were blocked for $2 \mathrm{~h}$ at room temperature with PBS containing 3\% bovine serum albumin, followed by four rinses with PBS-T. Then, $100 \mu \mathrm{L}$ of 1:100 serum dilutions in PBS-T were incubated for $2 \mathrm{~h}$ at room temperature, followed by five rinses with PBS-T. The plates were then incubated with the optimal dilutions of mouse anti-sea bass IgM monoclonal antibody (Aquatic Diagnostics Ltd.) and secondary anti-mouse IgG-HRP (Sigma-Aldrich). The absorbance was read at $450 \mathrm{~nm}$ in a plate reader (BMG Labtech). Negative controls consisted of samples without serum or without coating. Sera from NNV-infected sea bass were also used as positive control.

\subsection{Gene expression}

Total RNA was isolated from TRIzol Reagent frozen samples following the manufacturer's instructions. One microgram of total RNA was treated with DNAse I to remove genomic DNA, and the first strand of cDNA was synthesized by reverse transcription using the SuperScript IV Reverse Transcriptase (Thermo Fisher) with random hexamers (Thermo Fisher).

The expression of the genes coding for (i) type I IFN pathway, (ii) B cell markers and immunoglobulins and (iii) $\mathrm{T}$ cell markers proteins were analysed by real-time PCR, performed with an ABI PRISM 7500 instrument (Applied Biosystems) using SYBR Green PCR Core Reagents (Applied Biosystems) as previously described [31]. The specific primers used were designed using the Oligo Perfect software tool (Invitrogen) and are shown in Supplementary Table 1. Prior to the experiments, the specificity of each primer pair was studied using positive and negative samples. A melting curve analysis of the amplified products validated the primers for specificity. Negative controls with no template were always included in the reactions. For each mRNA sample, gene expression was corrected by the geometric average of the expression of two endogenous genes [elongation factor 1 alpha (ef1a) and tubulin alpha (tuba)] in each sample and expressed as $2^{-\Delta \Delta \mathrm{Ct}}$, where $\Delta \Delta \mathrm{Ct}$ is determined by subtracting the endogenous $\mathrm{Ct}$ geometric average value from the target $\mathrm{Ct}$ and referring to the respective control group.

\subsection{Statistical analysis}

Data were analysed by a t-Student test to establish differences between control and vaccinated groups at each time point $(P \leq 0.05)$. Data are represented as the mean \pm standard error of the mean (SEM). Cumulative mortality was represented for both groups as mean \pm SEM ( $n=2$ replicates). Statistical analyses were conducted using SPSS Statistical Software System version 15.0 (SPSS Inc.).

\section{Results}

\section{1. rNNV production}

Recombinant bacteria were selected and the production of rNNV protein fused to $\mathrm{N}$-terminal $6 \times$ His tested by electrophoresis and western blotting (Fig. 1). Results showed that bacteria contain few positive bands before induction with arabinose. After induction, Ponceau $\mathrm{S}$ staining for total proteins (Fig. 1A) showed a very prominent band of around $48 \mathrm{kDa}$, which corresponds to the recombinant NNV capsid protein (Fig. 1B) as evidenced by the immunoblotting.

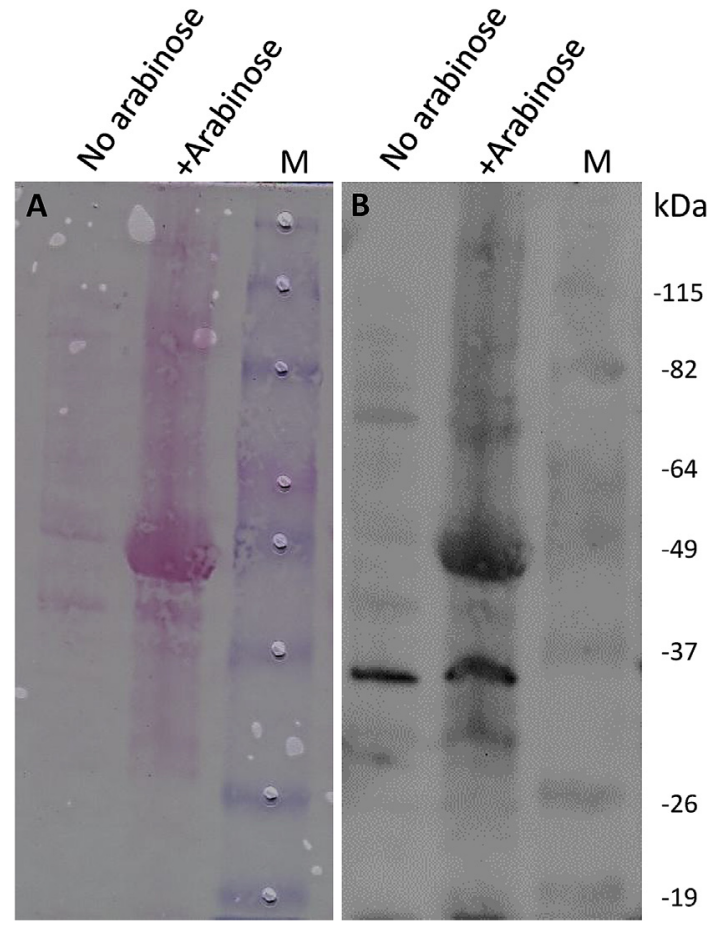

Fig. 1. Recombinant NNV capsid vaccine (rNNV) production in bacteria Bacteria were lysed, electrophoresed and proteins transferred to a nylon membrane, which was either stained with Ponceau $S$ for total protein (A) or used for immunoblotting with anti-His antibody (B). Bacterial cultures before and after induction with L-arabinose were tested. $\mathrm{M}$, marker.

\section{2. rNNV vaccine increases specific IgM levels}

The levels of specific anti-NNV IgM was determined in European sea bass serum by ELISA. After 30 days of vaccination, both administration routes produced significant increments in the specific anti-NNV IgM although the intraperitoneal route produced higher antibody levels (Fig. 2). In addition, when vaccinated fish were challenged with NNV the IgM titters were further increased, being highest now in fish vaccinated by the oral route.

\section{3. rNNV vaccination slightly affects the immunity at gene level}

In Fig. 3, we show the fold change in the expression of genes related to IFN ( $m x$ and isg15), immunoglobulin (ighm and ight) and T-cell markers ( $c d 8 a$ and $c d 4$ ) in HK, posterior gut and brain. Surprisingly, very little differences reached significance. Thus, ip vaccination resulted in decreased ight transcription in the HK after $30 \mathrm{dpv}$ while oral vaccination did in the $c d 4$ mRNA levels at $30 \mathrm{dpv}$ and $2 \mathrm{dpi}$. P values for the comparison between groups is denoted in Supplementary Table 2.

\subsection{Recombinant vaccine elicits great protection after challenge}

Fish were challenged at $30 \mathrm{dpv}$ (Fig. 4) and the mortalities recorded. In the control group, fish deaths were recorded from day 3 until day 10, reaching a low mortality of $33 \%$ and showing typical disease symptoms (data not shown), while in the rNNV vaccinated group by either route no fish death was recorded. Therefore, the rNNV vaccination elicited a RPS (relative percentage of survival) of $100 \%$.

\section{Discussion}

Aquaculture provides slightly over half of the fish production worldwide, being an industry of fast growing [34], therefore occurrence of viral outbreaks and associated mortality would result in important 


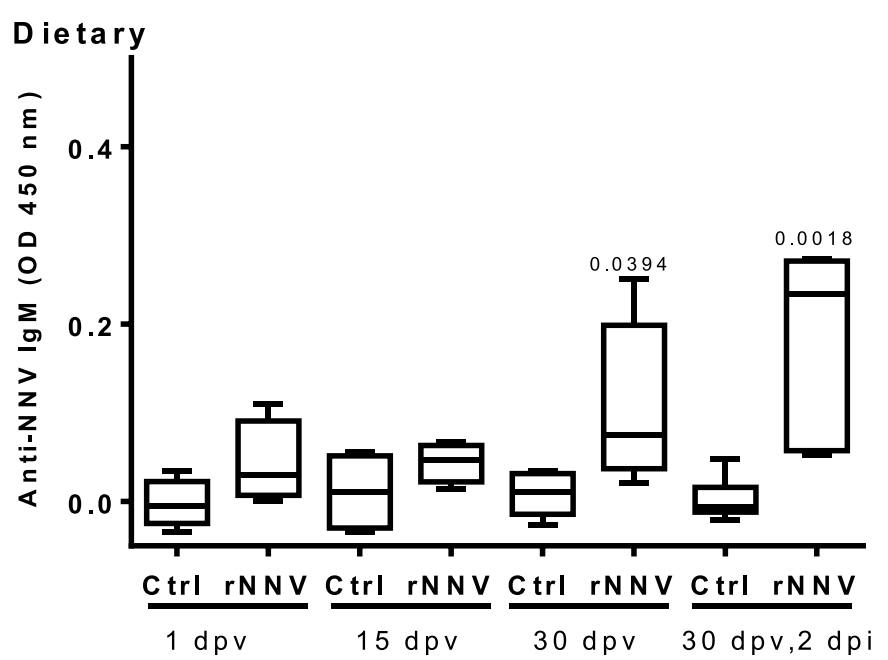

In traperitoneal

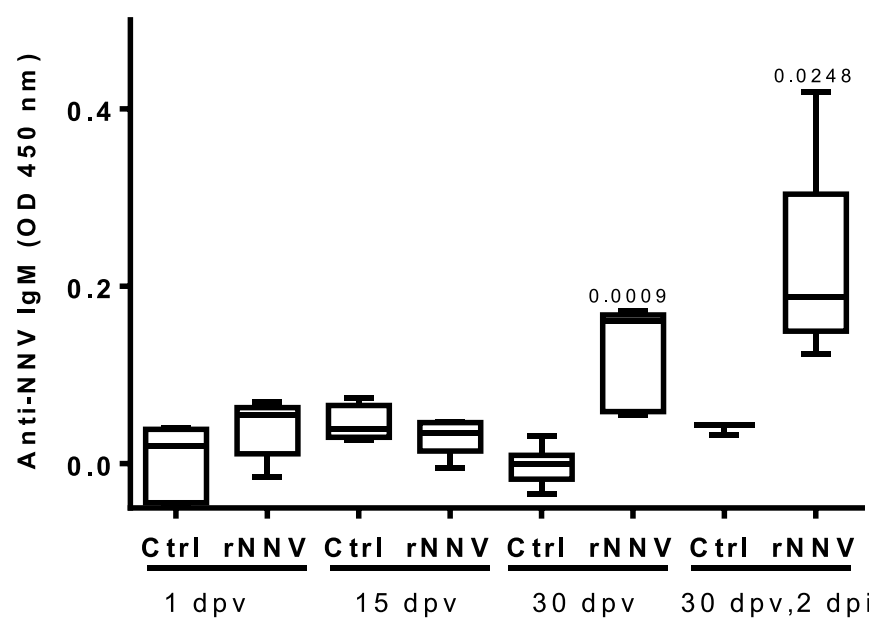

Fig. 2. Recombinant NNV vaccine (rNNV) induces specific antibodies. AntiNNV IgM levels in the serum of European sea bass receiving oral (whole bacteria) or intraperitoneally injected (lysed bacteria) rNNV vaccine produced in $E$. coli bacterium. Controls consisted on bacteria without rNNV. Data represent the mean \pm standard error of the mean (SEM; $n=6$ /group and time). Statistical significance between each vaccinated group and its respective control according to the t-Student test $(\mathrm{P}<0.05)$ is denoted. dpv, days post-vaccination; dpi, days post-infection.

economic loses. In this context, current research is focused in finding cost-effective antiviral treatments, being prevention through vaccination the most promising methodology. Different types of vaccines against NNV have been generated, the recombinant vaccines providing encouraging results. Thus, bacteria can express peptides or the complete capsid protein, which might auto-assemble to form VLPs [35,36] resembling native virus but without containing viral genome, which are further purified for vaccination by intraperitoneal injection. Nevertheless, handling and anesthetizing are stressful procedures, and the injection is not practical in small fish, which indeed, are the most susceptible to disease. By contrast, oral administration can be applied to a high number of juveniles and larvae at the same time, saving time and avoiding stress to fish and should be further explored.

We have developed and tested a recombinant vaccine, delivered without any purification steps, thus $E$. coli acted as an adjuvant. In general terms, we obtained the same efficacy of our recombinant vaccine independently of the administration method, which demonstrates the stability and the antigenic properties of the synthesized capsid protein delivered without any purification steps. To our knowledge, this is the first report of a recombinant vaccine administered to European sea bass providing a $100 \%$ survival upon NNV challenge. Our results surpass most of those using purified recombinant NNV vaccines [14,16-19,23-27]. The success of our vaccine can be partly explained by the generation of specific anti-NNV IgM in vaccinated fish, which further responded to NNV infection increasing IgM titters, especially in the oral vaccinated group. Synthesis of either total and/or neutralizing specific antibodies against nodavirus has been already found in European sea bass and other fish species upon nodavirus vaccination. In most of the studies NNV resistance has been achieved after vaccination with recombinant NNV vaccines that is partly explained by increased antibody levels [14,16-19,23-27]. This fact points to the correct induction of fish immunity by the recombinant proteins and generation of IgM. Unfortunately, our results about gene expression are somehow contradictory since we failed to detect important differences in the expression of the studied genes in comparison with control groups. Perhaps, this is due to high fish-to-fish variability and the fact that control groups also received whole or lysed E. coli, and it could be acting as a potent immunostimulant, regulating the expression of the studied genes and masking a possible regulation due to the rNNV protein in the vaccine. Previous studies have demonstrated early upregulation of some key immune genes encoding type-I IFN genes, Ig, Tcell markers or cytokines among others after vaccination with recombinant or inactivated NNV vaccines [13,21,33,37]. In sharp contrast to our data, although it is known the early induction and protective role of type-I IFN by NNV infection or vaccines [13,38-40] few studies have documented increased expression of IFN-related genes 2-4 weeks after vaccination with NNV [31,41,42]. This could be due to the presence of viral RNA, or a very reduced ability to viral proliferation, from the inactivated vaccine formulations. Unfortunately, any study has documented this late expression of IFN-related genes after vaccination with recombinant vaccines, which could be due to the absence of viral RNA. Interestingly, inactivated NNV vaccination of European sea bass resulted partly protective with increased antibacterial and antiviral activities and IgM levels in serum though the expression of immune genes in the HK was down-regulated [33] as it occurs in this study. Strikingly, though this was not significant, oral injection of rNNV resulted in a general pattern of transcript down-regulation in the gut 30 $\mathrm{dpv}$ while this fact was reversed after challenge, suggesting some gut specific immune response. In addition, though the viral challenge produced little mortality all the genes evaluated in vaccinated European sea bass specimens showed a decreased transcription in the brain. This suggest that the low levels of NNV were probably cleared by the circulating IgM in vaccinated fish before the virus can reach the target tissues. Further studies are needed to understand the mechanism by with NNV vaccines operate in European sea bass.

To conclude, we have developed an E. coli-produced recombinant vaccine for NNV, suitable to be administered without any purification by both oral and intraperitoneal injection routes, obtaining a survival rate of $100 \%$ in European sea bass juveniles. Mechanistically, vaccination elicited specific anti-NNV IgM but failed to affect the expression of immune transcripts, what deserves further studies to be understood. Both administration routes showed similar results, demonstrating that oral vaccination can be successfully applied to protect European sea bass from NNV, which is more appropriate for large scale vaccination avoiding stressful, labour intensive and costly procedures.

\section{Conflicts of interest}

The authors declare no conflict of interests.

\section{Acknowledgments}

Grants AGL2013-43588-P and AGL2016-74866-C3-1-R (MINECO and FEDER), 19883/GERM/15 (Fundación Séneca de la Región de Murcia, Spain) and NODAMED (Instituto Español de Oceanografía) are 

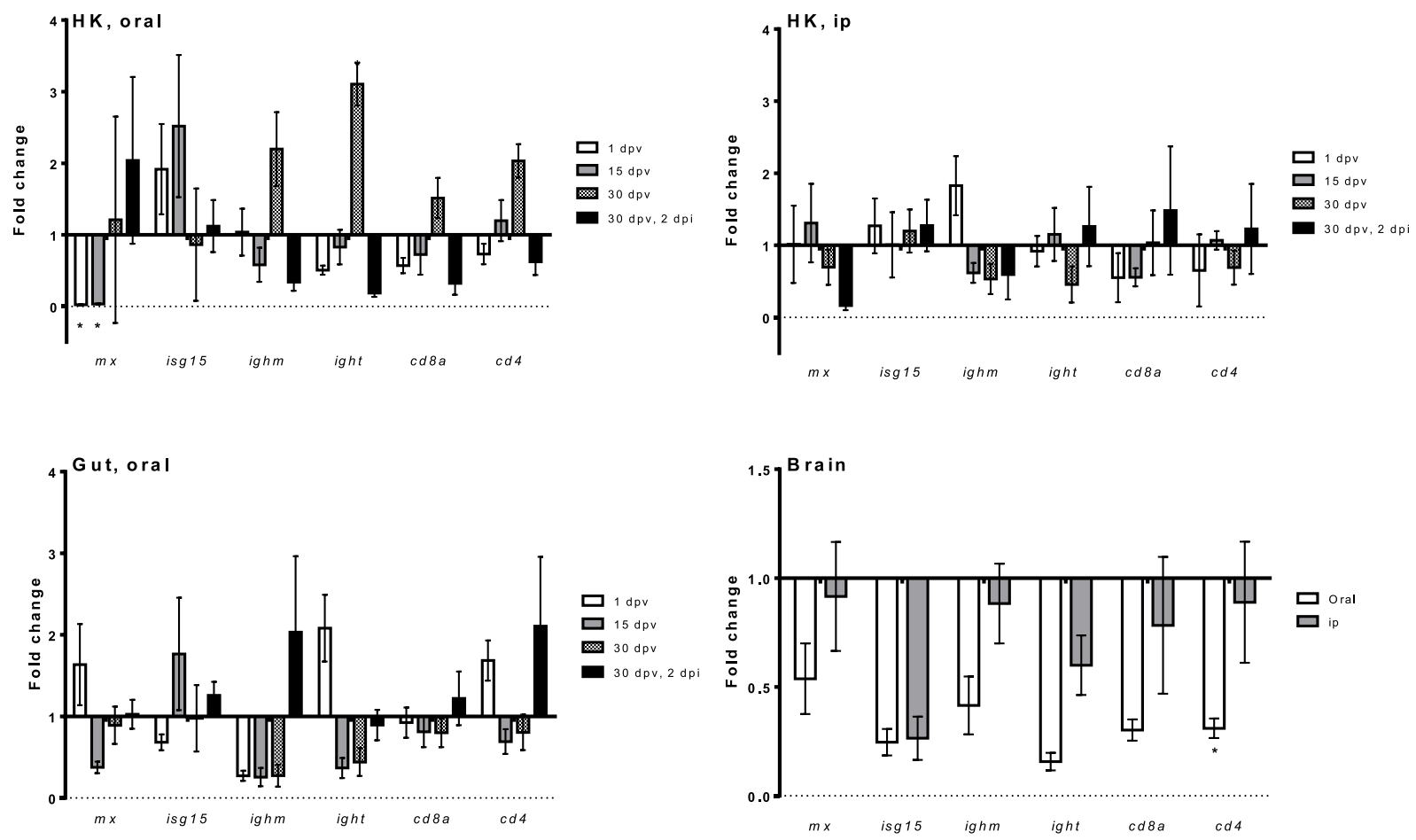

Fig. 3. Immune-related genes are slightly regulated upon recombinant NNV vaccination. Gene expression in head-kidney, posterior gut or brain of European sea bass receiving oral (whole bacteria) or intraperitoneally injected (lysed bacteria) rNNV vaccine produced in $E$. coli bacterium. Controls consisted on bacteria without rNNV. Data are expressed as mean \pm SEM ( 6 fish per group and time) relative to the respective controls without rNNV. Statistical significance between each vaccinated group and its respective control according to the t-Student test $(\mathrm{P}<0.05)$ is denoted. HK, head-kidney; ip, intraperitoneal; dpv, days post-vaccination; dpi, days post-infection.

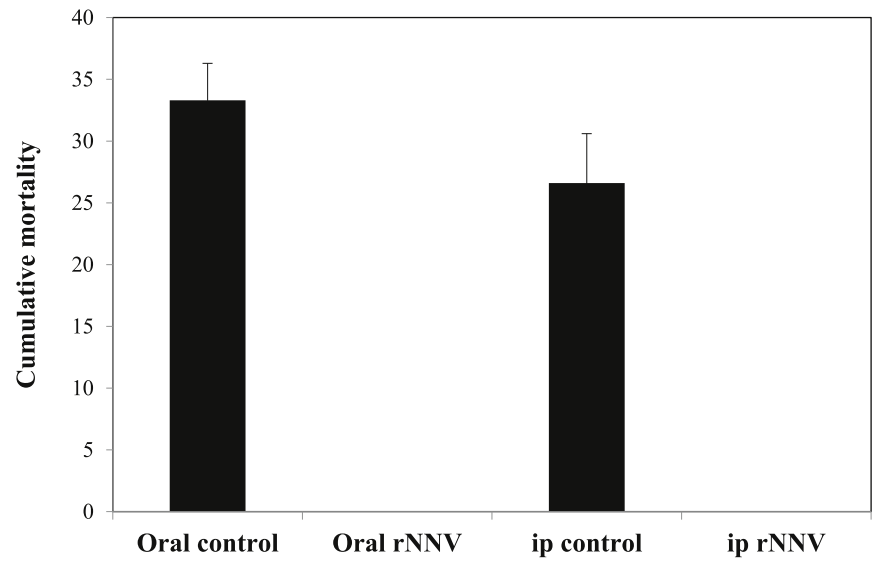

Fig. 4. Vaccine rNNV produces complete protection. Cumulative mortality of European sea bass juveniles after intramuscular injection with $10^{6} \mathrm{TCID}_{50} \mathrm{NNV}$ per fish 30 days after oral or intraperitoneal vaccination with the recombinant rNNV capsid protein vaccine and their respective controls. Bars show the mean cumulative mortality \pm SEM ( $\mathrm{n}=2$ replicates). Both vaccination routes produced a $100 \%$ protection.

gratefully acknowledged. Nodavirus strain was kindly donated by Pilar Fernández Somalo (Laboratorio Central de Veterinaria de Algete, Ministerio de Medio Ambiente, Rural y Marino), provided by the Instituto Zooprofilattico Sperimentale delle Venezie (Italy).

\section{Appendix A. Supplementary data}

Supplementary data to this article can be found online at https:// doi.org/10.1016/j.fsi.2019.03.013.

\section{References}

[1] J.Z. Costa, K.D. Thompson, Understanding the interaction between Betanodavirus and its host for the development of prophylactic measures for viral encephalopathy and retinopathy, Fish Shellfish Immunol. 53 (2016) 35-49, https://doi.org/10. 1016/j.fsi.2016.03.033.

[2] B.L. Munday, J. Kwang, N. Moody, Betanodavirus infections of teleost fish: a review, J. Fish Dis. 25 (2002) 127-142, https://doi.org/10.1046/j.1365-2761.2002. 00350.x.

[3] Q.K. Doan, M. Vandeputte, B. Chatain, T. Morin, F. Allal, Viral encephalopathy and retinopathy in aquaculture: a review, J. Fish Dis. 40 (2017) 717-742, https://doi. org/10.1111/jfd.12541.

[4] K. Mori, T. Nakai, K. Muroga, M. Arimoto, K. Mushiake, I. Furusawa, Properties of a new virus belonging to nodaviridae found in larval striped jack (Pseudocaranx dentex), Virology 187 (1992) 368-371.

[5] C.-F. Low, B. Syarul Nataqain, H.-Y. Chee, M.Z.H. Rozaini, M. Najiah, Betanodavirus: dissection of the viral life cycle, J. Fish Dis. 40 (2017) 1489-1496, https://doi.org/10.1111/jfd.12638.

[6] B.J. Fenner, W. Goh, J. Kwang, Dissection of double-stranded RNA binding protein B2 from Betanodavirus, J. Virol. 81 (2007) 5449-5459, https://doi.org/10.1128/ JVI.00009-07.

[7] K.L. Johnson, B.D. Price, L.A. Ball, Recovery of infectivity from cDNA clones of nodamura virus and identification of small nonstructural proteins, Virology 305 (2003) 436-451.

[8] T. Iwamoto, K. Mise, A. Takeda, Y. Okinaka, K.-I. Mori, M. Arimoto, T. Okuno, T. Nakai, Characterization of Striped jack nervous necrosis virus subgenomic RNA3 and biological activities of its encoded protein B2, J. Gen. Virol. 86 (2005) 2807-2816, https://doi.org/10.1099/vir.0.80902-0.

[9] L.-J. Chen, Y.-C. Su, J.-R. Hong, Betanodavirus non-structural protein B1: a novel anti-necrotic death factor that modulates cell death in early replication cycle in fish cells, Virology 385 (2009) 444-454, https://doi.org/10.1016/j.virol.2008.11.048.

[10] Y.-C. Su, J.-L. Wu, J.-R. Hong, Betanodavirus non-structural protein B2: a novel necrotic death factor that induces mitochondria-mediated cell death in fish cells, Virology 385 (2009) 143-154, https://doi.org/10.1016/j.virol.2008.11.036.

[11] S. Grotmol, G. Totland, Surface disinfection of Atlantic halibut Hippoglossus hippoglossus eggs with ozonated sea-water inactivates nodavirus and increases survival of the larvae, Dis. Aquat. Org. 39 (2000) 89-96, https://doi.org/10.3354/dao039089.

[12] K. Watanabe, T. Nishizawa, M. Yoshimizu, Selection of brood stock candidates of barfin flounder using an ELISA system with recombinant protein of barfin flounder nervous necrosis virus, Dis. Aquat. Org. 41 (2000) 219-223, https://doi.org/10. 3354/dao041219.

[13] F. Buonocore, N. Nuñez-Ortiz, S. Picchietti, E. Randelli, V. Stocchi, L. Guerra, A. Toffan, F. Pascoli, A.M. Fausto, M. Mazzini, G. Scapigliati, Vaccination and 
immune responses of European sea bass (Dicentrarchus labrax L.) against betanodavirus, Fish Shellfish Immunol. (2017), https://doi.org/10.1016/j.fsi.2017.11. 039.

[14] I. Sommerset, R. Skern, E. Biering, H. Bleie, I.U. Fiksdal, S. Grove, A.H. Nerland, Protection against Atlantic halibut nodavirus in turbot is induced by recombinan capsid protein vaccination but not following DNA vaccination, Fish Shellfish Immunol. 18 (2005) 13-29, https://doi.org/10.1016/j.fsi.2004.03.006.

[15] A.-C. Overgård, S. Patel, O.J. Nøstbakken, A.H. Nerland, Atlantic halibut (Hippoglossus hippoglossus L.) T-cell and cytokine response after vaccination and challenge with nodavirus, Vaccine 31 (2013) 2395-2402, https://doi.org/10.1016/ j.vaccine.2013.01.034

[16] S. Húsgard, S. Grotmol, B. Hjeltnes, O. Rødseth, E. Biering, Immune response to a recombinant capsid protein of striped jack nervous necrosis virus (SJNNV) in turbot Scophthalmus maximus and Atlantic halibut Hippoglossus hippoglossus, and evaluation of a vaccine against SJNNV, Dis. Aquat. Org. 45 (2001) 33-44, https://doi.org/10. 3354 /dao045033.

[17] J.-L. Coeurdacier, F. Laporte, J.-F. Pepin, Preliminary approach to find synthetic peptides from nodavirus capsid potentially protective against sea bass viral encephalopathy and retinopathy, Fish Shellfish Immunol. 14 (2003) 435-447.

[18] R. Thiery, J. Cozien, J. Cabon, F. Lamour, M. Baud, A. Schneemann, Induction of a protective immune response against viral nervous necrosis in the European sea bass Dicentrarchus labrax by using Betanodavirus virus-like particles, J. Virol. 80 (2006) 10201-10207, https://doi.org/10.1128/JVI.01098-06.

[19] S. Vimal, N. Madan, M.A. Farook, K.S.N. Nambi, S.A. Majeed, T. Rajkumar, S. Venu, A.R. Thirunavukkarasu, A.S.S. Hameed, Production of recombinant vaccine using capsid gene of nodavirus to protect Asian sea bass, Lates calcarifer (Bloch, 1790), Aquaculture 418-419 (2014) 148-154, https://doi.org/10.1016/J. AQUACULTURE.2013.10.017.

[20] S. Tanaka, K. Mori, M. Arimoto, T. Iwamoto, T. Nakai, Protective immunity of sevenband grouper, Epinephelus septemfasciatus Thunberg, against experimental viral nervous necrosis, J. Fish Dis. 24 (2001) 15-22, https://doi.org/10.1046/j.13652761.2001.00259.X.

[21] Y.-X. Lai, B.-L. Jin, Y. Xu, L. Huang, R.-Q. Huang, Y. Zhang, J. Kwang, J.-G. He, J.F. Xie, Immune responses of orange-spotted grouper, Epinephelus coioides, against virus-like particles of betanodavirus produced in Escherichia coli, Vet. Immunol. Immunopathol. 157 (2014) 87-96, https://doi.org/10.1016/j.vetimm.2013.10. 003.

[22] K. Lin, Z. Zhu, H. Ge, L. Zheng, Z. Huang, S. Wu, Immunity to nervous necrosis virus infections of orange-spotted grouper (Epinephelus coioides) by vaccination with virus-like particles, Fish Shellfish Immunol. 56 (2016) 136-143, https://doi.org/10. 1016/j.fsi.2016.06.056.

[23] M.-H. Chien, S.-Y. Wu, C.-H. Lin, Oral immunization with cell-free self-assembly virus-like particles against orange-spotted grouper nervous necrosis virus in grouper larvae, Epinephelus coioides, Vet. Immunol. Immunopathol. 197 (2018) 69-75, https://doi.org/10.1016/j.vetimm.2018.01.012.

[24] Y.-M. Chen, C.-H. Shih, H.-C. Liu, C.-L. Wu, C.-C. Lin, H.-C. Wang, T.-Y. Chen, H.L. Yang, J.H.-Y. Lin, An oral nervous necrosis virus vaccine using Vibrio anguillarum as an expression host provides early protection, Aquaculture 321 (2011) 26-33, https://doi.org/10.1016/J.AQUACULTURE.2011.08.035.

[25] S.Y. Cho, H.J. Kim, N.T. Lan, H.-J. Han, D.-C. Lee, J.Y. Hwang, M.-G. Kwon, B.K. Kang, S.Y. Han, H. Moon, H.A. Kang, H.-J. Kim, Oral vaccination through voluntary consumption of the convict grouper Epinephelus septemfasciatus with yeast producing the capsid protein of red-spotted grouper nervous necrosis virus, Vet. Microbiol. 204 (2017) 159-164, https://doi.org/10.1016/j.vetmic.2017.04.022.

[26] G.R. Wi, J.Y. Hwang, M.-G. Kwon, H.J. Kim, H.A. Kang, H.-J. Kim, Protective immunity against nervous necrosis virus in convict grouper Epinephelus septemfasciatus following vaccination with virus-like particles produced in yeast Saccharomyces cerevisiae, Vet. Microbiol. 177 (2015) 214-218, https://doi.org/10.1016/j.vetmic. 2015.02 .021$.

[27] C.-C. Lin, J.H.-Y. Lin, M.-S. Chen, H.-L. Yang, An oral nervous necrosis virus vaccine that induces protective immunity in larvae of grouper (Epinephelus coioides), Aquaculture 268 (2007) 265-273, https://doi.org/10.1016/J.AQUACULTURE. 2007.04.066.

[28] K. Yuasa, I. Koesharyani, D. Roza, K. Mori, M. Katata, T. Nakai, Immune response of humpback grouper, Cromileptes altivelis (Valenciennes) injected with the recombinant coat protein of betanodavirus, J. Fish Dis. 25 (2002) 53-56, https://doi. org/10.1046/j.1365-2761.2002.00325.x.

[29] C.-F. Lin, H.-K. Jiang, N.-C. Chen, T.-Y. Wang, T.-Y. Chen, Novel subunit vaccine with linear array epitope protect giant grouper against nervous necrosis virus infection, Fish Shellfish Immunol. 74 (2018) 551-558, https://doi.org/10.1016/j.fsi. 2018.01.029.

[30] S. Vimal, S. Abdul Majeed, K.S.N. Nambi, N. Madan, M.A. Farook, C. Venkatesan, G. Taju, S. Venu, R. Subburaj, A.R. Thirunavukkarasu, A.S. Sahul Hameed, Delivery of DNA vaccine using chitosan-tripolyphosphate (CS/TPP) nanoparticles in Asian sea bass, Lates calcarifer (Bloch, 1790) for protection against nodavirus infection, Aquaculture 420-421 (2014) 240-246, https://doi.org/10.1016/J. AQUACULTURE. 2013.11.017.

[31] Y. Valero, E. Awad, F. Buonocore, M. Arizcun, M.Á. Esteban, J. Meseguer, E. Chaves-Pozo, A. Cuesta, An oral chitosan DNA vaccine against nodavirus improves transcription of cell-mediated cytotoxicity and interferon genes in the European sea bass juveniles gut and survival upon infection, Dev. Comp. Immunol. 65 (2016) 64-72, https://doi.org/10.1016/j.dci.2016.06.021.

[32] L.J. Reed, H. Muench, A simple method of estimating fifty per cent endpoints, Am. J. Epidemiol. 27 (1938) 493-497, https://doi.org/10.1093/oxfordjournals.aje. a118408.

[33] Y. Valero, D. Mokrani, E. Chaves-Pozo, M. Arizcun, M. Oumouna, J. Meseguer, M.Á. Esteban, A. Cuesta, Vaccination with UV-inactivated nodavirus partly protects European sea bass against infection, while inducing few changes in immunity, Dev. Comp. Immunol. 86 (2018) 171-179, https://doi.org/10.1016/j.dci.2018.05.013.

[34] FAO, The State of World Fisheries and Aquaculture - Meeting the Sustainable Development Goals, (2018).

[35] N.T. Lan, H.J. Kim, H.-J. Han, D.-C. Lee, B.K. Kang, S.Y. Han, H. Moon, H.-J. Kim, Stability of virus-like particles of red-spotted grouper nervous necrosis virus in the aqueous state, and the vaccine potential of lyophilized particles, Biologicals 51 (2018) 25-31, https://doi.org/10.1016/j.biologicals.2017.11.002.

[36] L. Tang, C. Lin, N.K. Krishna, M. Yeager, A. Schneemann, J.E. Johnson, Virus-like particles of a fish nodavirus display a capsid subunit domain organization differen from that of insect nodaviruses, J. Virol. (2002) 6370-6375, https://doi.org/10. 1128/JVI.76.12.6370-6375.2002.

[37] M.-W. Lu, W. Liu, C.-S. Lin, Infection competition against grouper nervous necrosis virus by virus-like particles produced in Escherichia coli, J. Gen. Virol. 84 (2003) 1577-1582, https://doi.org/10.1099/vir.0.18649-0.

[38] E. Gomez-Casado, A. Estepa, J.M. Coll, A comparative review on European-farmed finfish RNA viruses and their vaccines, Vaccine 29 (2011) 2657-2671, https://doi org/10.1016/J.VACCINE. 2011.01.097.

[39] Y.-M. Chen, T.-Y. Wang, T.-Y. Chen, Immunity to betanodavirus infections of marine fish, Dev. Comp. Immunol. 43 (2014) 174-183, https://doi.org/10.1016/J DCI. 2013.07.019.

[40] N. Nuñez-Ortiz, F. Pascoli, S. Picchietti, F. Buonocore, C. Bernini, M. Toson, G. Scapigliati, A. Toffan, A formalin-inactivated immunogen against viral encephalopathy and retinopathy (VER) disease in European sea bass (Dicentrarchus labrax): immunological and protection effects, Vet. Res. 47 (2016) 89, https://doi. org/10.1186/s13567-016-0376-3.

[41] Y.-H. Kai, Y.-C. Wu, S.-C. Chi, Immune gene expressions in grouper larvae (Epinephelus coioides) induced by bath and oral vaccinations with inactivated betanodavirus, Fish Shellfish Immunol. 40 (2014) 563-569, https://doi.org/10.1016/ J.FSI.2014.08.005.

[42] Y.-K. Cheng, Y.-C. Wu, S.-C. Chi, Humoral and cytokine responses in giant groupers after vaccination and challenge with betanodavirus, Dev. Comp. Immunol. 67 (2017) 385-394, https://doi.org/10.1016/j.dci.2016.08.013. 